\title{
Relationship of coregulator and oestrogen receptor isoform expression to de novo tamoxifen resistance in human breast cancer
}

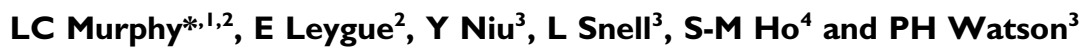 \\ 'Manitoba Institute of Cell Biology, University of Manitoba, Faculty of Medicine, Winnipeg, Manitoba, Canada, R3E OW3; ${ }^{2}$ Department of Biochemistry and \\ Medical Genetics, University of Manitoba, Faculty of Medicine, Winnipeg, Manitoba, Canada, R3E OW3; ${ }^{3}$ Department of Pathology, University of \\ Manitoba, Faculty of Medicine, Winnipeg, Manitoba, Canada, R3E OW3; ${ }^{4}$ Department of Surgery, University of Massachusetts Medical School, \\ Worchester. Massachusetts, MA 01655, USA
}

This study addresses the hypothesis that altered expression of oestrogen receptor-beta and/or altered relative expression of coactivators and corepressors of oestrogen receptors are associated with and may be mechanisms of de novo tamoxifen resistance in oestrogen receptor positive breast cancer. All cases were oestrogen receptor + , node negative, primary breast tumours from patients who later had no disease progression (tamoxifen sensitive) or whose disease progressed while on tamoxifen (tamoxifen resistant). Using an antibody to oestrogen receptor-beta that detects multiple forms of this protein (total) but not an antibody that detects only full-length oestrogen receptor-beta I, it was found that high total oestrogen receptor beta protein expressors were more frequently observed in tamoxifen sensitive tumours than resistant tumours (Fisher's exact test, $P=0.046$ ). However, no significant differences in the relative expression of oestrogen receptor $\beta 2$, oestrogen receptor $\beta 5$ and full-length oestrogen receptor $\beta$ । RNA in the tamoxifen sensitive and resistant groups were found. Also, when the relative expression of two known coactivators, steroid receptor RNA activator and amplified in breast cancer I RNA to the known corepressor, repressor of oestrogen receptor activity RNA, was examined, no significant differences between the tamoxifen sensitive and resistant groups were found. Altogether, there is little evidence for altered coregulators expression in breast tumours that are de novo tamoxifen resistant. However, our data provide preliminary evidence that the expression of oestrogen receptor $\beta$ protein isoforms may differ in primary tumours of breast cancer patients who prove to have differential sensitivity to tamoxifen therapy.

British Journal of Cancer (2002) 87, I4II-1416. doi:10.1038/sj.bjc.6600654 www.bjcancer.com

(c) 2002 Cancer Research UK

Keywords: SRA; AIBI; ROA; coregulators; OR isoforms; human breast cancer; tamoxifen

The ability of anti-oestrogens such as tamoxifen to compete with oestrogens for binding to $\mathrm{OR}$ and to antagonise their mitogenic action provides the basic rationale for endocrine therapy and prevention (for a review see (Osborne, 1998b) in breast cancer. Adjuvant tamoxifen post-operative therapy reduces the number of recurrences and prolongs survival in women whose primary tumours are oestrogen receptor (OR) positive (Group, 1998). However, even though OR level is considered a marker for predicting the likelihood of responding to adjuvant hormonal therapies, some patients, whose primary tumours are OR positive do not respond to tamoxifen treatment. Such apparent de novo tamoxifen resistance does not depend upon the level of OR within the primary tumour. As well many of those patients whose disease initially responds to tamoxifen, progress while still under treatment having acquired resistance and this occurs despite continued expression of OR. Thus suggesting other components

*Correspondence: Dr LC Murphy; Manitoba Institute of Cell Biology, CancerCare Manitoba, 675 McDermot Ave, Winnipeg, MB. R3E OV9, Canada; E-mail: Icmurph@cc.umanitoba.ca

Received I July 2002; revised 4 September 2002; accepted 19 September 2002 of the oestrogen signalling pathway may be altered. Recent observations using laboratory models (Hall and McDonnell, 1999; Lanz et al, 1999; McKenna et al, 1999; Montano et al, 1999) have demonstrated that altered levels of OR isoforms and/or alteration of expression of coactivators and corepressors can deregulate oestrogen and antioestrogen activity in target cells, suggesting the hypothesis that altered levels of OR isoforms and/or coregulators in vivo could be a mechanism of tamoxifen resistance. Previously we have demonstrated that the relative expression of $\mathrm{OR} \alpha / \mathrm{OR} \beta$ as well as the relative expression of some OR coactivators to corepressors is significantly altered during breast tumourigenesis in vivo (Leygue et al, 1998; Murphy et al, 2000). Furthermore, since these alterations parallel the marked changes in oestrogen action that accompany breast tumourigenesis, they may have a role in this process. To explore the hypothesis that such changes could underlie de novo tamoxifen resistance in vivo, the expression of OR isoforms, two known coactivators (steroid receptor RNA activator (SRA), (Lanz et al, 1999) and amplified in breast cancer-1 (AIB1) (Anzick et al, 1997) ) and one corepressor (repressor of oestrogen receptor activity, repressor of oestrogen receptor activity (ROA) (Montano et $a l, 1999)$ ) of OR activity have been investigated in primary breast tumours from node negative patients whose tumours were OR 
positive and that subsequently responded or had disease progression while on adjuvant tamoxifen therapy.

\section{MATERIALS AND METHODS}

\section{Human breast tumours}

All breast tumour cases used for this study were selected from the NCIC-Manitoba Breast Tumour Bank (Winnipeg, Manitoba, Canada). As previously described (Hiller et al, 1996), tissues are accrued to the Bank from cases at multiple centres within Manitoba, rapidly collected and processed to create matched formalin-fixedembedded and frozen tissue blocks for each case with the mirror image surfaces oriented by coloured inks. The histology of every sample in the Bank is uniformly interpreted by a pathologist in Hematoxylin/Eosin (H\&E) stained sections from the face of the paraffin tissue block. This information is available in a computerized database along with relevant pathological and clinical information and was used as a guide for selection of specific paraffin and frozen blocks from cases for this study. For each case, interpretations included an estimate of the cellular composition (including the percentage of invasive epithelial tumour cells and stroma), tumour type and tumour grade (Nottingham score). Steroid receptor status was determined for all cases by ligand binding assay performed on an adjacent portion of tumour tissue. Tumours with oestrogen receptor levels above $3 \mathrm{fmol} \mathrm{mg}^{-1}$ of total protein were considered OR positive.

To identify cases that responded divergently to tamoxifen, review of approximately 1000 consecutive cases was undertaken to identify cases that were OR positive, node negative and that had been treated with adjuvant tamoxifen following surgery $+/-$ local radiation. From these the first cohort of 27 cases was selected to include a subset $(n=13)$ that had shown progression of disease (either died or alive with recurrent disease, referred to as tamoxifen resistant cases) and a similar control subset $(n=14)$ specifically selected to comprise cases with similar lengths of follow-up, OR status, tumour grade and tumour histology, but that had shown no progression of disease (referred to as tamoxifen sensitive cases). The tumour characteristics were: (1) 'Tam Sensitive' group median OR was $60.5 \mathrm{fmol} \mathrm{mg}{ }^{-1}$ protein (range $6-146 \mathrm{fmol} \mathrm{mg}^{-1}$ protein), median $\mathrm{PR}$ was $32 \mathrm{fmol} \mathrm{mg}^{-1}$ protein (range $8-216 \mathrm{fmol} \mathrm{mg}{ }^{-1}$ protein); median grade was five (range 4-8); median age at biopsy was 69 years (range 35-87 years); median follow-up time was 56 months (range 18-79); (2) 'Tam Resistant' group median OR was $57 \mathrm{fmol} \mathrm{mg}{ }^{-1}$ protein (range $4-136 \mathrm{fmol} \mathrm{mg}^{-1}$ protein); median $\mathrm{PR}$ was $14 \mathrm{fmol} \mathrm{mg}^{-1}$ protein (range $4-288 \mathrm{fmol} \mathrm{mg}^{-1}$ protein); median grade was six (range 4-9); median age at biopsy was 67 years (range 49-83 years); median follow-up time was 56 months (range 9-85).

For the RNA studies, frozen tissue corresponding to the blocks for several of the first cohort of older cases used above, were not available. Therefore, after further review of the tumour bank as described above, a second study cohort was selected that also had frozen tissue available. The relevant patient/tumour characteristics were similar to the above cohort, although the follow-up time was shorter: (1) 'Tam Sensitive' group $(n=16)$ median OR was $37.5 \mathrm{fmol} \mathrm{mg}^{-1}$ protein (range 4.4-146 fmol mg ${ }^{-1}$ protein), median PR was $44 \mathrm{fmol} \mathrm{mg}^{-1}$ protein (range 13.1-216 fmol $\mathrm{mg}^{-1}$ protein); median grade was six (range 4-9); median age at biopsy was 72 years (range 47-87 years); median follow-up time was 39 months (range 13-76); (2) 'Tam Resistant' group $(n=16)$ median OR was $21.5 \mathrm{fmol} \mathrm{mg}^{-1}$ protein (range $5.6-107 \mathrm{fmol} \mathrm{mg}^{-1}$ protein); median PR was $14.3 \mathrm{fmol} \mathrm{mg}^{-1}$ protein (range $7.8-288 \mathrm{fmol} \mathrm{mg}^{-1}$ protein); median grade was six (range 4-9); median age at biopsy was 71 years (range 60-89 years); median follow-up time was 34 months (range 9-63).

\section{Immunohistochemistry}

Immunohistochemistry was performed on serial $5 \mu \mathrm{m}$ sections from a representative, formalin fixed paraffin embedded archival tissue block from each tumour. Immunohistochemical staining for $\operatorname{OR} \beta$ was performed using two different primary antibodies. IgYERB503 (a gift from Dr Jan-Ake Gustafson) detects total OR $\beta$ isoforms (Horvath et al, 2001; Saji et al, 2000) and GC17 (a gift from Dr Shuk-Mei Ho) detects only the full-length OR $\beta$ (Leav et $a l$, 2001). The GC17 polyclonal antibody was raised in rabbits against a peptide sequence in the $\mathrm{F}$ domain of the human OR- $\beta$ receptor (amino acids 449 to 465) and its specificity validated previously (Leav et al, 2001). The epitope to which the IgYERB503 antibody is directed is not known, but this polyclonal chicken antibody was raised to an $\mathrm{OR} \beta$ recombinant protein which was disrupted in the ligand binding domain by insertion of 18 additional amino acids, but was subsequently shown to also recognise the full-length non-inserted OR $\beta$ protein (Saji et al, 2000). Antibodies were applied using an automated tissue immunostainer (Discovery module, Ventana Medical Systems, Phoenix, AZ, USA), DAB immunohistochemistry kit and bulk reagents that were supplied by the manufacturer. Briefly, the Discovery staining protocol was set to 'Standard Cell Conditioning' procedure, followed by $12 \mathrm{~h}$ incubation with primary antibody and $32 \mathrm{~min}$ incubation with secondary antibody. Concentrations of primary antibodies initially applied to the Ventana instrument were $1: 200$ for IgYERB503 and $1: 50$ for GC17, which translates into final concentrations of $1: 600$ and $1: 150$ after a $1: 3$ dilution with buffer dispensed onto the slide with the primary antibody. Levels of nuclear $\operatorname{OR} \beta$ expression were scored semi-quantitatively, under the light microscope. Scores were obtained by estimating average signal intensity (on a scale of $0-300$ ) and the proportion of epithelial cells showing a positive signal (0, none; 0.1 , less than one tenth; 0.5 , less than one half; 1.0 greater than one half). The intensity and proportion scores were then multiplied to give an overall IHC-score. Cases with a score lower than or equal to 100 were considered negative or weakly positive, whereas tumours with scores higher than 100 were classified as positive for OR $\beta$ expression (Al-Haddad et al, 1999).

\section{RNA Extraction and RT - PCR conditions}

Total RNA was extracted from $20 \mu \mathrm{m}$ frozen tissue sections $(20$ sections per tumour) using Trizol ${ }^{\mathrm{TM}}$ reagent (Life Technologies, NY, USA) according to the manufacturer's instructions and quantified spectrophotometrically. One $\mu \mathrm{g}$ of total RNA was reverse transcribed in a final volume of $25 \mu \mathrm{l}$ as previously described (Leygue et al, 1996).

\section{Primers and PCR conditions}

Coregulators The primers used were: SRAcoreU primer (5'AGGAACGCGGCTGGAACGA-3'; sense; positions 35-53, Genbank accession number AF092038) and SRAcoreL primer (5'AGTCTGGGGAACCGAGGAT-3'; antisense; position 696-678, Genbank accession number AF092038); AIB1-U primer (5'ATACTTGCTGGATGGTGGACT-3'; sense; positions $110-130$, Genbank accession number AF012108) and AIB1-L primer (5'TCCTTGCTCTTTTATTTG ACG-3'; antisense; positions $458-$ 438, Genbank accession number AF012108); ROA-U primer (5'CGAAAAATCTCCTCCССTACA-3'; sense; positions 385-405, Genbank accession number AF150962) and ROA-L primer (5'CCTGCTTTGCTTTTTCTACCA-3'; antisense; positions 781-761, Genbank accession number AF150962).

Radioactive PCR amplifications for SRA were performed and PCR products analysed as previously described (Leygue et al, 1999b) with minor modifications. Briefly, $1 \mu \mathrm{l}$ of reverse transcrip- 
tion mixture was amplified in a final volume of $15 \mu \mathrm{l}$, in the presence of $1.5 \mu \mathrm{Ci}$ of $\left(\alpha_{-}{ }^{32} \mathrm{P}\right) \mathrm{dCTP}\left(3000 \mathrm{Ci} \mathrm{mmol}^{-1}\right), 4 \mathrm{ng} \mu \mathrm{l}^{-1}$ of each primer and 0.3 unit of Taq DNA polymerase (Gibco BRL, Grand Island, NY, USA). For SRA each PCR consisted of 30 cycles $\left(30 \mathrm{~s}\right.$ at $94^{\circ} \mathrm{C}, 30 \mathrm{~s}$ at $60^{\circ} \mathrm{C}$ and $30 \mathrm{~s}$ at $72^{\circ} \mathrm{C}$ ). PCR products were then separated on $6 \%$ polyacrylamide gels containing $7 \mathrm{M}$ urea. Following electrophoresis, the gels were dried and exposed $2 \mathrm{~h}$ to a Molecular Imager ${ }^{\mathrm{TM}}$-FX Imaging screen (Bio-Rad, Hercules, CA, USA).

PCR amplifications for AIB1 and ROA were performed and PCR products analysed as previously described (Leygue et al, 1996) with minor modifications. Briefly, $1 \mu \mathrm{l}$ of reverse transcription mixture was amplified in a final volume of $20 \mu \mathrm{l}$, in the presence of

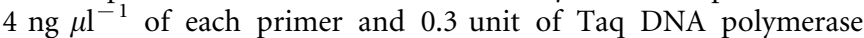
(Gibco BRL, Grand Island, NY, USA). For AIB1, each PCR consisted of 30 cycles $\left(30 \mathrm{~s}\right.$ at $94^{\circ} \mathrm{C}, 30 \mathrm{~s}$ at $55^{\circ} \mathrm{C}$ and $30 \mathrm{~s}$ at $\left.72^{\circ} \mathrm{C}\right)$. For ROA each PCR consisted of 30 cycles $\left(30 \mathrm{~s}\right.$ at $94^{\circ} \mathrm{C}$, $30 \mathrm{~s}$ at $57^{\circ} \mathrm{C}$ and $30 \mathrm{~s}$ at $72^{\circ} \mathrm{C}$ ). PCR products were then separated on agarose gels stained with ethidium bromide as previously described (Leygue et al, 1996).

\section{Primers for OR isoforms}

OR $\alpha$-U primer (5'-TGTGCAATGACTATGCTTCA-3'; sense; located in OR $\alpha$ 792-811) and OR $\alpha$-L primer (5'-GCTCTTCCTCCTGTTTTTA-3'; antisense; located in OR $\alpha$ 940-922). Nucleotide positions given correspond to published sequences of the human OR $\alpha$ cDNA (Green et al, 1986). PCR amplifications were performed and PCR products analysed as previously described with minor modifications (Dotzlaw et al, 1997). Briefly, $1 \mu \mathrm{l}$ of reverse transcription mixture was amplified in a final volume of $15 \mu \mathrm{l}$, in the presence of $1 \mu \mathrm{Ci}\left(\alpha_{-}{ }^{32} \mathrm{P}\right) \mathrm{dCTP}\left(3000 \mathrm{Ci} \mathrm{mmol}^{-1}\right)$, $2 \mathrm{ng} \mu \mathrm{l}^{-1}$ of $\mathrm{OR} \alpha-\mathrm{U} / \mathrm{OR} \alpha-\mathrm{L}$ and 0.3 unit of Taq DNA polymerase (Gibco BRL, Grand Island, NY, USA). Each PCR consisted of 30 cycles $\left(30 \mathrm{~s}\right.$ at $94^{\circ} \mathrm{C}, 30 \mathrm{~s}$ at $60^{\circ} \mathrm{C}$ and $30 \mathrm{~s}$ at $72^{\circ} \mathrm{C}$ ).

A previously validated triple primer assay was used to determine the relative expression of $\mathrm{OR} \beta 1$ and its variant isoforms $\mathrm{OR} \beta 2$ and OR $\beta 5$ (Leygue et al, 1999a). Briefly, $1 \mu \mathrm{l}$ of reverse transcription mixture was amplified in a final volume of $15 \mu \mathrm{l}$, in the presence

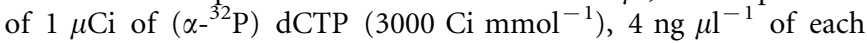
primer $(\mathrm{OR} \beta 1 \mathrm{U}, \mathrm{OR} \beta 1 \mathrm{~L}$ and $\mathrm{OR} \beta 2 \mathrm{~L})$ and 0.3 unit of Taq DNA polymerase (Gibco BRL, Grand Island, NY, USA).

All OR PCRs consisted of 30 cycles $\left(30 \mathrm{~s}\right.$ at $94^{\circ} \mathrm{C}, 30 \mathrm{~s}$ at $60^{\circ} \mathrm{C}$, and $30 \mathrm{~s}$ at $72^{\circ} \mathrm{C}$ ). PCR products were then separated on $6 \%$ polyacrylamide gels containing $7 \mathrm{M}$ urea. Following electrophoresis, the gels were dried and autoradiographed. Three independent PCRs were performed.

Quantification of SRA and OR RNA expression Exposed screens were scanned using a Molecular Imager ${ }^{\mathrm{TM}}$-FX (Bio-Rad, Hercules, CA, USA) and the intensity of the signal corresponding to SRA or the appropriate OR isoform PCR fragments was measured using Quantity One $\mathrm{TM}^{\mathrm{TM}}$ software (Bio-Rad, Hercules, CA, USA). Three independent PCRs were performed. In order to control for variations between experiments, a value of 1 was arbitrarily assigned to the signal of one particular tumour measured in each set of PCR experiments (always the same tumour) and all signals were expressed relative to this signal. Levels of SRA was expressed relative to ROA (SRA/ROA), AIB1 (SRA/AIB1) or OR $\alpha$ $(\mathrm{SRA} / \mathrm{OR} \alpha)$ in each individual tumour sample. Levels of $\operatorname{OR} \beta$ isoforms were expressed relative to other $\mathrm{OR} \beta$ isoforms shown under statistical analysis and as previously described (Leygue et al, 1999a).

Quantification of the relative expression of the deleted SRA variant RNA It has previously been shown that the coamplification of a full-length and a deleted variant SRA (SRA-Del) cDNA resulted in the amplification of two PCR products, the relative signal intensity of which provided a reliable measurement of the relative expression of the deleted variant (Leygue et al, 1999b). For each sample, the signal corresponding to the SRA-Del was measured using Quantity One $\mathrm{TM}^{\mathrm{TM}}$ software (Bio-Rad, Hercules, CA, USA) and expressed as a percentage of the corresponding core SRA signal. For each case, three independent assays were performed and the mean determined.

Quantification of ROA and AIB1 RNA expression Following analysis of PCR products on prestained agarose gels, signals were quantified by scanning using MultiAnalyst ${ }^{\mathrm{TM}}$ (Bio-Rad, Hercules, CA, USA). At least, three independent PCRs were performed. A value of 1 was arbitrarily assigned to the ROA or AIB1 signal of one particular tumour and is the same tumour as described above and all signals were expressed relative to this signal. Levels of AIB1 were expressed relative to ROA (AIB1/ROA) and OR $\alpha$ (AIB1/ $\mathrm{OR} \alpha$ ), and levels of ROA were expressed relative to OR $\alpha$ (ROA/ $\mathrm{OR} \alpha)$.

Statistical analysis Differences between tamoxifen sensitive and tamoxifen resistant cases were tested using the Mann-Whitney rank sum test, two-tailed. Potential differences in expression between the two groups with respect to each $\mathrm{OR} \beta$ isoform RNA relative to other OR $\beta$ isoform RNA expression (e.g. $\log$ OR $\beta 1 /$ total $\mathrm{OR} \beta ; \log \mathrm{OR} \beta 2 /$ total $\mathrm{OR} \beta ; \log \mathrm{OR} \beta 5 /$ total $\mathrm{OR} \beta$, as previously described (Leygue et al, 1999a)), and the relative expressions of coregulators (i.e. $\log \mathrm{AIB} 1 / \mathrm{ROA} ; \quad \operatorname{logSRA} / \mathrm{ROA}$; logSRA/AIB1; $\log \mathrm{AIB} 1 / \mathrm{OR} \alpha ; \operatorname{logSRA} / \mathrm{OR} \alpha ; \operatorname{logROA} / \mathrm{OR} \alpha)$ were determined.

Tumours were classified as low (scores between 0 and 100) and high $(150-300)$ OR $\beta$ expressors, and differences between tamoxifen sensitive and tamoxifen resistant cases were tested using Fisher's exact test. Correlation between $\mathrm{OR} \beta$ protein expression (IHC-score) and tumour characteristics was tested by calculation of the Spearman coefficient $r$.

\section{RESULTS}

\section{Expression of $\mathrm{OR} \beta$ protein in primary human breast tumours from patients who later progressed on tamoxifen treatment or showed no progression on tamoxifen treatment}

$\mathrm{OR} \beta$ protein was determined immunohistochemically on adjacent sections from each tumour, using two different antibodies. GC17 is an antibody recognizing an epitope in the C-terminus of full-length OR $\beta 1$ (Leav et al, 2001). Normal breast tissue was used as a positive control and is shown in Figure 1A. Examples of staining in human breast tumour sections are shown in Figure $1 \mathrm{~B}-\mathrm{D}$. Some tumour sections showed no (Figure 1B, full-length $\mathrm{OR} \beta$ score $=0$ ) or low (Figure 1C, full-length $\operatorname{OR} \beta$ score $=100$ ), while others showed strong full-length OR $\beta$ signals (Figure 1D, wild-type OR $\beta$ score $=300$ ). Tumours were classified as low (scores between 0 and 100) and high $(150-300)$ full-length $\mathrm{OR} \beta$ protein expressors, and differences between tamoxifen sensitive and resistant tumours determined by Fisher's exact test. No significant differences were found.

IgYERbeta503 is an antibody that recognises ligand binding and non-ligand binding OR $\beta$ protein isoforms (Horvath et al, 2001; Saji et al, 2000) and which we refer to as total OR $\beta$ protein. Normal breast tissue was used as a positive control and is shown in Figure 2A. Examples of staining with this antibody in human breast tumour sections are shown in Figure $2 \mathrm{~B}-\mathrm{D}$. Some sections showed no (Figure $2 \mathrm{~B}$, total $\mathrm{OR} \beta$ score $=0$ ) or low (Figure $2 \mathrm{C}$, total $\mathrm{OR} \beta$ score $=100)$ total $\mathrm{OR} \beta$ expression whereas others had strong total $\mathrm{OR} \beta$ protein signal (Figure $2 \mathrm{D}$, total $\mathrm{OR} \beta$ score=300). 


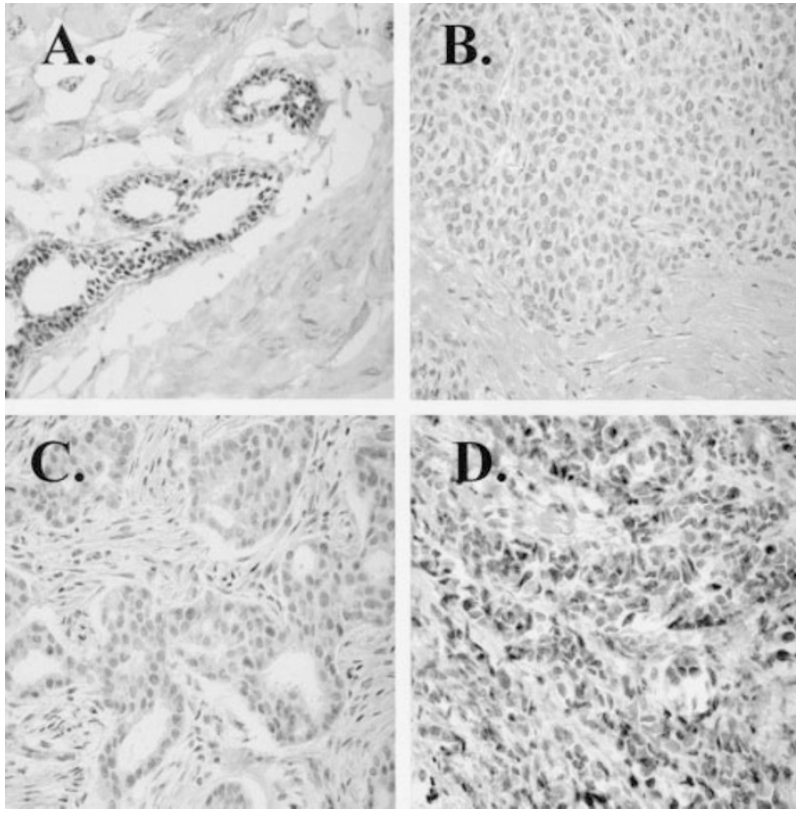

Figure I Examples of immunohistochemistry using the GC- 17 antibody which only recognises the full-length $\mathrm{OR} \beta \mathrm{I}$ : $(\mathbf{A})$ normal human breast tissue; (B) OR $\beta$ I negative human breast tumour, $\mathrm{H}$-score=0; (C) $\mathrm{OR} \beta$ I low expressing human breast tumour, $\mathrm{H}$-score= $=100$; (D) $O R \beta \mid$ high expressing human breast tumour, $\mathrm{H}$-score $=150$.

Tumours were classified as low and high total OR $\beta$ protein expressors, and there was a statistically significant difference in high total $\mathrm{OR} \beta$ protein between the Tamoxifen sensitive and resistant groups (Fisher's exact test, $P=0.046$ ). High total $\mathrm{OR} \beta$ protein expressors were more frequently observed in tamoxifen sensitive tumours than resistant tumours.

Correlation between $\mathrm{OR} \beta$ protein expression and tumour characteristics was tested by calculation of the Spearman coefficient. A positive correlation between $\mathrm{OR} \beta 1$ (GC17) protein and progesterone receptor (PR) levels (Spearman $r=0.44, P=0.022$ ) was found when each was examined as continuous variables. When tumours were divided into $\mathrm{PR}+\left(>10 \mathrm{fmol} \mathrm{mg}^{-1}\right.$ protein $)$ or $\mathrm{PR}-$ $\left(\leqslant 10 \mathrm{fmol} \mathrm{mg}{ }^{-1}\right.$ protein) groups there was a significantly higher level of $\mathrm{OR} \beta 1$ (GC17) protein in $\mathrm{PR}+$ tumours compared to $\mathrm{PR}$ - tumours (Mann - Whitney test, $P=0.0268$; median for $\mathrm{PR}+$ tumours $=55$, range 5-150 and median for $P R-$ tumours $=10$, range $0-75)$. As well, there was also a significantly higher level of total $\mathrm{OR} \beta$ (IgY503) protein in $\mathrm{PR}+$ tumours compared to $\mathrm{PR}$ - tumours (Mann - Whitney test, $P=0.0085$; median for $\mathrm{PR}+$ tumours $=125$, range $25-270$ and median for $P R-$ tumours $=50$ range $0-100)$.

Relative expression of $O R \beta$ isoform RNA in primary human breast tumours from patients who later progressed on tamoxifen treatment or showed no progression on adjuvant tamoxifen To determine if the differences described above in $\mathrm{OR} \beta$ protein expression were correlated with differences in OR $\beta$ variant isoform RNA expression, we compared the relative expression of $\mathrm{OR} \beta$ variant RNA to full-length $\mathrm{OR} \beta$ RNA in the tamoxifen sensitive and resistant groups. Unfortunately, frozen tissue samples corresponding to many of the paraffin blocks from patients in the cohort used for immunohistochemistry were not available. Therefore additional cases selected were selected from the tumourbank as described in Materials and Methods. Using previously validated assays (Leygue et al, 1998; 1999a) the relative expression of $\mathrm{OR} \beta 2, \operatorname{OR} \beta 5$ and full-length $\mathrm{OR} \beta 1$

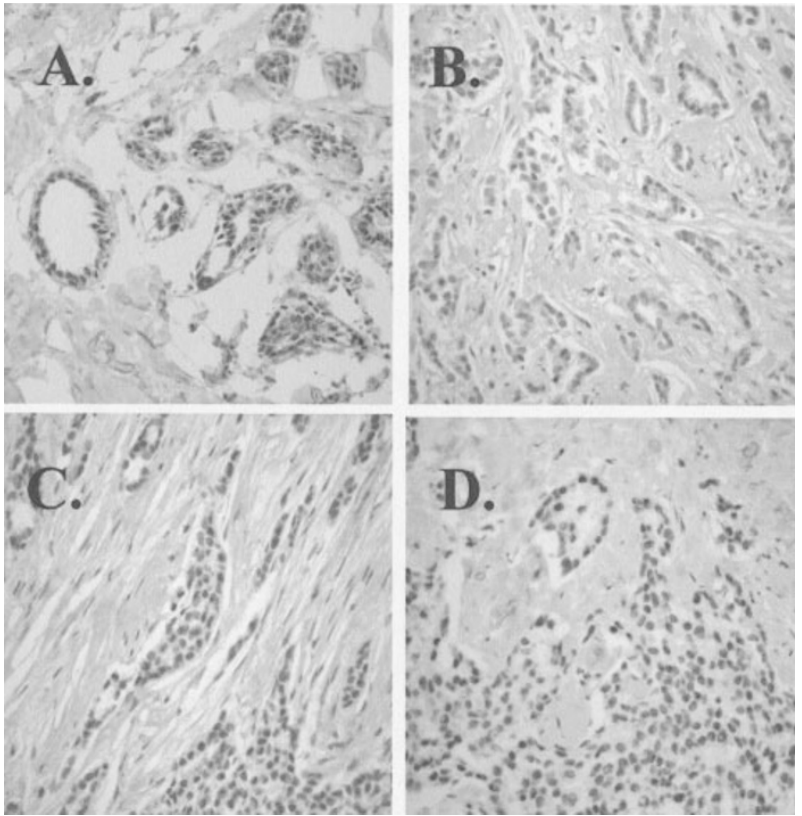

Figure 2 Examples of immunohistochemistry using the $\lg Y E R \beta 503$ antibody which recognises most $O R \beta$ isoforms: $(\mathbf{A})$ normal human breast tissue; (B) $\mathrm{OR} \beta$ negative human breast tumour, $\mathrm{H}$-score $=25$; (C) $\mathrm{OR} \beta$ low expressing human breast tumour, $\mathrm{H}$-score=I00; (D) OR $\beta$ high expressing human breast tumour, $\mathrm{H}$-score $=225$.

RNA in the tamoxifen sensitive and resistant groups was not significantly different.

Relative expression of coregulators in primary human breast tumours from patients who later progressed on tamoxifen treatment or showed no progression on tamoxifen treatment To address the hypothesis that altered relative expression of steroid receptor coactivators and corepressors could underlie altered tamoxifen sensitivity in human breast tumours, and since we previously showed that the relative expression of two coactivators (SRA and AIB1) to a corepressor (ROA) is altered in OR+ breast tumours compared their adjacent normal breast tissue, we chose these coregulators to study. They were measured by RT PCR in the above tumour cohorts. SRA, AIB1, and ROA mRNAs were detectable in most samples, even though their level of expression differed from one sample to another. Consistent with our previous results (Leygue et al, 1999b), an additional fragment, migrating at an apparent size of $459 \mathrm{bp}$ was also observed in most tumours when using SRA specific primers. Sequencing analysis revealed that this band corresponded to a variant form of SRA (referred to as SRA-Del) deleted in 203 bp between positions 155 and 357 (positions given correspond to Genbank accession number AF092038). There were no significant differences between the tamoxifen sensitive and the de novo tamoxifen resistant breast cancers in the relative expression of any of the coactivators to corepressor RNA, or in the relative expression of SRA/AIB1 RNA, or in expression of any of these coregulator RNAs relative to $\mathrm{OR} \alpha$ or total OR $\beta$ RNA expression. As well, there was no significant difference in the relative expression of variant SRA/full-length SRA between the groups either.

Tumour characteristics No statistically significant differences were found between the tamoxifen sensitive and tamoxifen resistant cohorts in any of the tumour characteristics described in the Materials and Methods section except for PR. PR levels were statistically significantly different $(P=0.044)$ between the two groups 
using a Mann - Whitney rank sum test (two sided). PR levels were higher (median PR was $32 \mathrm{fmol} \mathrm{mg}^{-1}$ protein; range $8-$ $216 \mathrm{fmol} \mathrm{mg}^{-1}$ protein) in the tamoxifen 'sensitive' group compared to the tamoxifen 'de novo resistant' group (median PR was $14 \mathrm{fmol} \mathrm{mg} \mathrm{mg}^{-1}$ protein; range $4-288 \mathrm{fmol} \mathrm{mg}^{-1}$ protein). This was a consistent finding in both selected cohorts (that used for immunohistochemistry and that used for the RNA study), and provides strong support for differences in oestrogen signalling pathways in these two groups since PR is a marker of OR signal transduction (Horwitz et al, 1975; Osborne, 1998a).

\section{DISCUSSION}

We and others have shown that the relative expression of $\mathrm{OR} \alpha$ and $\operatorname{OR} \beta$ is significantly altered during breast tumourigenesis (Leygue et al, 1998; Roger et al, 2001), and a similar mechanism has been proposed to underlie tamoxifen resistance in breast cancers (Paech et al, 1997). The current study shows no significant differences in expression of full-length $\operatorname{OR} \beta(\operatorname{OR} \beta 1)$ between tamoxifen sensitive and resistant tumours. Interestingly, in this small cohort of tumours when total $\mathrm{OR} \beta$ expression was examined, there were significantly more high total $\operatorname{OR} \beta$ expressors in the tamoxifen 'sensitive' compared to the 'resistant' group. The data suggest the possibility that increased and altered $\operatorname{OR} \beta$ isoform protein expression may have a role in de novo tamoxifen resistance, or at least together with other parameters may provide better markers of endocrine sensitivity. The increased expression of OR $\beta$ proteins in the tamoxifen sensitive group is also consistent with recently published data where patients with $\operatorname{OR} \beta$ positive tumours (determined using an antibody to an N-terminal epitope of the $\operatorname{OR} \beta$ protein, and defined as nuclear staining in $>10 \%$ of cancer cells) had a significantly better overall survival than patients with $\operatorname{OR} \beta$ negative tumours while receiving adjuvant tamoxifen therapy (Mann et al, 2001). Both these latter data and those presented currently in this manuscript are in contrast to data showing increased $\operatorname{OR} \beta$ RNA expression in tamoxifen resistant tumours versus tamoxifen sensitive tumours previously published (Speirs et al, 1999). Together these studies suggest that the $\operatorname{OR} \beta$ status and the nature of $\mathrm{OR} \beta$ isoforms together with $\mathrm{OR} \alpha$ status in human breast cancers may be important biomarkers of endocrine sensitivity, and warrants further study, in larger, prospectively gathered cohorts. The association of increased OR $\beta$ isoform expression with tamoxifen sensitivity, suggests a possible mechanistic role, and one possible mechanism may be suggested by several publications which have shown that $\mathrm{OR} \beta$ isoforms have a modulatory effect on OR $\alpha$, both in normal tissues (Weihua et al, 2000) as well as in cell culture models (Ogawa et al, 1998; Hall and McDonnell, 1999).

The potential difference between tamoxifen sensitive and resistant groups with respect to OR $\beta$-like proteins, was not correlated with differences in the relative expression of full-length $\operatorname{OR} \beta$ and

\section{REFERENCES}

Al-haddad S, Zhang Z, Leygue E, Snell L, Huang A, Niu Y, Hiller-Hitchcock T, Hole K, Murphy L, Watson P (1999) Psoriasin (S100A7) expression and invasive breast cancer. Am J Pathol 155: 2057-2066

Anzick S, Kononen J, Walker R, Azorsa D, Tanner M, Guan X, Sauter G, Kallioniemi O, Trent J, Meltzer P (1997) AIB1, a steroid receptor coactivator amplified in breast and ovarian cancer. Science 277: 965-968

Dotzlaw H, Leygue E, Watson P, Murphy L (1997) Expression of estrogen receptor-beta in human breast tumors. J Clin Endocrinol Metabol 82: $2371-2374$

Fuqua S, Schiff R, Parra I, Friedrichs W, Su J, McKee D, Slentz-Kesler K, Moore L, Willson T, Moore J (1999) Expression of wild-type estrogen receptor beta and variant isoforms in human breast cancer. Cancer Res 59: $5425-5428$ two known variants $\mathrm{OR} \beta 2$ and $\mathrm{OR} \beta 5$ at the RNA level between the tamoxifen 'sensitive' versus the tamoxifen 'resistant' groups, however. This may be due to differential regulation of protein versus RNA level or the likelihood that there are other potential $\mathrm{OR} \beta$ isoforms (known and unknown) expressed in breast tissues in addition to OR $\beta 1, \mathrm{OR} \beta 2$ and OR $\beta 5$ (Lu et al, 1998; Fuqua et $a l, 1999)$, whose cognate proteins would be detected by the antibody but not measured in the triple primer RT-PCR assay.

Another mechanism for differential tamoxifen sensitivity in OR+ breast tumours could be altered coregulator expression. Although the relative expression of OR coregulators SRA, AIB1 and ROA is altered between normal breast and OR+ breast tumours, there were no significant differences in the ratios of any of the coactivators/corepressors or any of the ratios of these coregulators to $\mathrm{OR} \alpha$ RNA levels between primary breast tumours from patients who were later found to be disease free (sensitive) or have disease progression (resistant) while on adjuvant tamoxifen treatment. These data suggest that altered relative expression of these coregulators is unlikely to be a marker of tamoxifen sensitivity in OR+, node negative, primary breast tumours, and unlikely to have a functional role in de novo tamoxifen resistance. Although SRA is functional as an RNA molecule, ROA and AIB1 are functional as proteins. Furthermore, other factors can affect protein activity for example phosphorylation in the case of AIB1 (Mora and Brown, 2000) or sequestration by other proteins such as prothymosinalpha in the case of ROA (Martini et al, 2000). Our studies do not exclude differences at the protein and/or activity levels of ROA and AIB1 being involved in de novo tamoxifen resistance, nor do they exclude altered expression of these factors having a role in acquired tamoxifen resistance (Lavinsky et al, 1998). Altogether, there is little evidence for altered coregulators expression in breast tumours that are de novo tamoxifen resistant. However, our data provide preliminary evidence that the expression of $\mathrm{OR} \beta$ protein isoforms may differ in primary tumours of breast cancer patients who prove to have differential sensitivity to tamoxifen therapy. As well our data support distinct differences in the OR signalling pathways between these two groups of patients since the expression of a known oestrogen responsive gene PR is significantly different between the two groups, the precise mechanisms underlying these differences remain to be elucidated.

\section{ACKNOWLEDGEMENTS}

This work was supported by grants from the Canadian Breast Cancer Research Initiative (CBCRI), the Canadian Institutes for Health Research (CIHR) and the US Army Medical Research and Materiel Command (USAMRMC). PH Watson is a recipient of a CIHR Scientist Award and a US Army Academic Award. E Leygue has a USAMRMC Career Development Award.
Green S, Walter P, Kumar V, Krust A, Bornert J, Argos P, Chambon P (1986) Human estrogen receptor cDNA: sequence, expression, and homology to v-erb-A. Nature 320: $134-139$

Group EBCT (1998) Tamoxifen for early breast cancer: an overview of the randomised trials. Lancet 351: 1451-1467

Hall J, McDonnell D (1999) The estrogen receptor beta-isoform (ERbeta) of the human estrogen receptor modulates ERalpha transcriptional activity and is a key regulator of the cellular response to estrogens and antiestrogens. Endocrinology 140: 5566-5578

Hiller T, Snell L, Watson P (1996) Microdissection/RT-PCR analysis of gene expression. Biotechniques 21: 38-44 
Horvath L, Henshall S, Lee C-S, Head D, Quinn D, Makela S, Delprado W Golovsky D, Brenner P, O’Neill G, Kooner R, Stricker P, Grygiel J, Gustafsson J-A, Sutherland R (2001) Frequent loss of estrogen receptor $\beta$ expression in prostate cancer. Cancer Res 61: 5331-5335

Horwitz KB, McGuire WL, Pearson OH, Segaloff A (1975) Predicting response to endocrine therapy in human breast cancer: a hypothesis. Science 189: $726-727$

Lanz R, McKenna N, Onate S, Albrecht U, Wong J, Tsai S, Tsai M-J, O’Malley B (1999) A steroid receptor coactivator, SRA, functions as an RNA and is present in an SRC-1 complex. Cell 97: 17-27

Lavinsky R, Jepsen K, Heinzel T, Torchia J, Mullen T, Schiff R, Del-Rio A, Ricote M, Ngo S, Gemsch J, Hilsenbeck S, Osborne C, Glass C, Rosenfeld M, Rose D (1998) Diverse signaling pathways modulate nuclear receptor recruitment of N-CoR and SMRT complexes. Proc Natl Acad Sci USA 95: $2920-2925$

Leav I, Lau K-M, Adams J, McNeal J, Taplin M-E, Wang J, Singh H, Ho S-M (2001) Comparative studies of the estrogen receptor $\beta$ and $\alpha$ and the androgen receptor in normal human prostate glands, dysplasia and in primary and metastatic carcinoma. Am J Pathol 159: 79-92

Leygue E, Dotzlaw H, Watson P, Murphy L (1998) Altered estrogen receptor alpha and beta mRNA expression during human breast tumorigenesis. Cancer Res 58: 3197-3201

Leygue E, Dotzlaw H, Watson P, Murphy L (1999a) Expression of estrogen receptor beta1, beta2, and beta5 messenger RNAs in human breast tissue. Cancer Res 59: $1175-1179$

Leygue E, Dotzlaw H, Watson P, Murphy L (1999b) Expression of the steroid receptor RNA activator (SRA) in human breast tumors. Cancer Res 59: $4190-4193$

Leygue E, Murphy L, Kuttenn F, Watson P (1996) Triple primer polymerase chain reaction. A new way to quantify truncated mRNA expression. Am J Pathol 148: $1097-1103$

Lu B, Leygue E, Dotzlaw H, Murphy L, Murphy L, Watson P (1998) Estrogen receptor-beta mRNA variants in human and murine tissues. Mol Cell Endocrinol 138: 199-203

Mann S, Laucirica R, Carlson N, Younes P, Ali N, Younes A, Li Y, Younes M (2001) Estrogen receptor beta expression in invasive breast cancer. Hum Pathol 32: $113-118$

Martini P, Delage-Mourroux R, Kraichely D, Katzenellenbogen B (2000) Prothymosin alpha selectively enhances estrogen receptor transcriptional activity by interacting with a repressor of estrogen receptor activity. Mol Cell Biol 20: 6224-6232
McKenna N, Lanz R, O’Malley B (1999) Nuclear receptor coregulators: cellular and molecular biology. Endocrine Rev 20: 321 - 344

Montano M, Ekena K, Delage-Mourroux R, Chang W, Martini P, Katzenellenbogen B (1999) An estrogen receptor-selective coregulator that potentiates the effectiveness of antiestrogens and represses the activity of estrogens. Proc Natl Acad Sci USA 96: 6947-6952

Mora JFD, Brown M (2000) AIB1 is a conduit for kinase-mediated growth factor signaling to the estrogen receptor. Mol Cell Biol 20: 5041-5047

Murphy L, Simon S, Parkes A, Leygue E, Dotzlaw H, Snell L, Troup S, Adeyinka A, Watson P (2000) Altered relative expression of estrogen receptor coregulators during human breast tumorigenesis. Cancer Res 60: $6266-627$

Ogawa S, Inoue S, Watanabe T, Orimo A, Hosoi T, Ouchi Y, Muramatsu M (1998) Molecular cloning and characterization of human estrogen receptor bcx: potential inhibitor of estrogen action in human. Nucleic Acids Res 26: $3505-3512$

Osborne C (1998a) Steroid hormone receptors in breast cancer management Breast Cancer Res Treat 51: 227-238

Osborne C (1998b) Tamoxifen in the treatment of breast cancer. N Engl J Med 339: $1609-1618$

Paech K, Webb P, Kuiper G, Nilsson S, Gustafsson J, Kushner PJ, Scanlan TS (1997) Differential Ligand Activation of Estrogen Receptors ERalpha and ERbeta at AP1 Sites. Science 277: 1508-1510

Roger P, Sahla M, Makela S, Gustafsson JA, Baldet P, Rochefort H (2001) Decreased expression of estrogen receptor beta protein in proliferative preinvasive mammary tumors. Cancer Res 61: 2537-2541

Saji S, Jensen E, Nilsson S, Rylander T, Warner M, Gustafsson J-A (2000) Estrogen receptors $\alpha$ and $\beta$ in the rodent mammary gland. Proc Natl Acad Sci USA 97: 337- 342

Speirs V, Malone C, Walton D, Kerin M, Atkin S (1999) Increased expression of estrogen receptor beta mRNA in tamoxifen-resistant breast cancer patients. Cancer Res 59: 5421-5424

Weihua Z, Saji S, Makinen S, Cheng G, Jensen EV, Warner M, Gustafsson JA (2000) Estrogen receptor (ER) $\beta$, a modulator of ER $\alpha$ in the uterus. Proc Natl Acad Sci 97: 5936-5941 